https://helda.helsinki.fi

\title{
Determination of the buffering capacity of postrigor meat
}

\section{Puolanne, Eero}

Elsevier

2000

Meat Science. 2000. 56(1): 7-13.

http://hdl.handle.net/1975/603

http://dx.doi.org/10.1016/S0309-1740(00)00007-3

Downloaded from Helda, University of Helsinki institutional repository.

This is an electronic reprint of the original article.

This reprint may differ from the original in pagination and typographic detail.

Please cite the original version. 
Eero Puolanne

Department of Food Technology/Meat Technology

University of Helsinki

Riitta Kivikari

Department of Applied Chemistry and Microbiology/Food Chemistry

University of Helsinki

\title{
DETERMINATION OF THE BUFFERING CAPACITY OF POSTRIGOR MEAT
}

\begin{abstract}
Since 1938 several studies on buffering capacity of postrigor meat have been presented. As the methods used have varied considerably it is important to know how to compare the results. The method of titration, mainly the amount of dilution used, has a significant effect on the shape of the obtained buffering capacity curve. When a dilute solution is used, the curve has distinct maximum and minimum points. With less dilution, the buffering capacity curve approaches a shape with no distinct minimum and maximum points in $\mathrm{pH}$ range 5.5-7.0. However, it seems possible to estimate the buffering capacity of meat from data based on titrations made with different dilutions. A mean value for buffering capacity valid in $\mathrm{pH}$ range 5.5-7.0 can be estimated from titrations made with dilution ratios 1:10 and 1:1. The mean buffering capacity values in $\mathrm{pH}$ range 5.5-7.0 were for beef $m$. longissimus muscle $51 \mathrm{mmol} \mathrm{H}^{+} /(\mathrm{pH} * \mathrm{~kg})$, for pork m. longissimus $52 \mathrm{mmol} \mathrm{H}^{+} /\left(\mathrm{pH}^{*} \mathrm{~kg}\right)$, for beef $m$. triceps brachii $48 \mathrm{mmol} \mathrm{H}^{+} /\left(\mathrm{pH}^{*} \mathrm{~kg}\right)$ and for pork $\mathrm{m}$. triceps brachii $45 \mathrm{mmol} \mathrm{H}^{+} /\left(\mathrm{pH}^{*} \mathrm{~kg}\right)$. For broiler breast and broiler leg-thigh muscles the corresponding values were 58 and $41 \mathrm{mmol} \mathrm{H}^{+} /\left(\mathrm{pH}^{*} \mathrm{~kg}\right)$.
\end{abstract}

Keywords: buffering capacity, meat 


\section{Introduction}

The first analysis of the buffering capacity of meat was published by Bate-Smith in 1938. In that study buffering capacities of several muscles from different species were determined by titrating with dilute acid or base. The roles of proteins, carnosine and orthophosphate in buffering capacity were also discussed. Since then several authors have presented values for buffering capacity $(\mathrm{BC})$ of meat, and many related variables have been studied, including changes in BC during post mortem reaction sequence (Hamm, 1959; Sayre et al., 1963), effect of heating (Hamm and Deatherage, 1960), different pig breeds (Sayre et al., 1963), different halothane types (Henckel et al., 1992), several species of fish, land and marine mammals (Castellini and Somero, 1981), light and dark beef muscles (Rao and Gault, 1989), and normal and PSE pigs (Bendall and Wismer-Pedersen, 1962). Table 1 summarizes the findings of results of these studies, although the varying methods used sometimes make it difficult to compare the results.

Light muscles usually have notably better buffering capacity than dark muscles. This is consistent, because they are comprised primarily of white muscle fibers, which have a high content of glycolytic enzymes. The end product of glycolytic metabolism is lactic acid, which tends to lower the $\mathrm{pH}$. Thus, white fibers need a more effective buffering mechanism than red ones. Buffering prolongs the time of effective fiber activity. The principal difference in the buffering capacity of different types of muscles is due to the fact that white fibers have a higher content of histidine compounds than red ones do (Olsman and Slump 1981).

The same compounds which regulate $\mathrm{pH}$ in a living muscle fiber also regulate it in postrigor meat. The compounds that most affect the buffering capacity in the $\mathrm{pH}$ range 5.5-7.0 are 1) phosphate compounds having $\mathrm{pK}_{\mathrm{a}}$ values between $6.1-7.1$; 2) histidylimidazole residues of myofibrillar proteins and 3) the dipeptides carnosine and anserine. Buffering capacity in this $\mathrm{pH}$ range caused by compounds other than the dipeptides can be considered constant between samples of varying fiber type compositions and also between species (Sewell et al., 1992). Consequently, variation in buffering capacity can be explained by variations in the amounts of dipeptides. 
Table 1. Buffering capacities of meat and myofibrils.

\begin{tabular}{|c|c|c|c|}
\hline reference & material & method $^{\mathrm{a}}$ & $\begin{array}{l}\text { buffering } \\
\text { capacity }^{\mathrm{b}}\end{array}$ \\
\hline $\begin{array}{l}\text { Bate-Smith } \\
1938\end{array}$ & $\begin{array}{l}\text { ox thigh } \\
\text { pork psoas }\end{array}$ & $\begin{array}{l}\text { dr: moistened with } \\
\text { saline } \\
\leftrightarrow \\
\text { range: } \mathrm{pH} \text { 5.5-7.5 }\end{array}$ & $\begin{array}{l}\text { range } 6-7 \\
\text { ox BC } 56 \\
\text { pork BC } 57\end{array}$ \\
\hline $\begin{array}{l}\text { Hamm and Deatherage } \\
1960\end{array}$ & beef $\mathrm{LD}^{\mathrm{c}}$ & $\begin{array}{l}\text { dr: } 1: 1 \\
\leftrightarrow \\
\text { range: } \mathrm{pH} 3-8\end{array}$ & $\begin{array}{l}\text { pHmax } 5.4 \\
\text { BCmax } 52\end{array}$ \\
\hline $\begin{array}{l}\text { Honikel and Hamm } \\
1974\end{array}$ & beef LD & $\begin{array}{l}\text { dr: } 1: 1 \\
\text { adj. to } \mathrm{pH} 9 \\
\text { range: } \mathrm{pH} 4-9\end{array}$ & $\begin{array}{l}\text { pHmin } 5.5 \\
\text { BCmin } 42 \\
\text { pHmax } 6.5 \\
\text { BCmax } 57\end{array}$ \\
\hline $\begin{array}{l}\text { Sayre et al. } \\
1964\end{array}$ & $\begin{array}{l}\text { pork LD } \\
3 \text { different breeds }\end{array}$ & $\begin{array}{l}\text { dr: } 1: 10 \\
\text { adj. to } \mathrm{pH} 4.8 \\
\text { range: } \mathrm{pH} 4.8-7\end{array}$ & $\begin{array}{l}\text { range } 5.2-6.5 \\
\mathrm{BC} 55\end{array}$ \\
\hline $\begin{array}{l}\text { Monin and Sellier } \\
1985\end{array}$ & $\begin{array}{l}\text { pork LD } \\
4 \text { different breeds }\end{array}$ & $\begin{array}{l}\text { dr: } 1: 10 \\
\text { adj. to } \mathrm{pH} 4.8 \\
\text { range: } \mathrm{pH} 4.8-7\end{array}$ & $\begin{array}{l}\text { range } 5.2-6.5 \\
\text { BC } 57\end{array}$ \\
\hline $\begin{array}{l}\text { Henckel et al. } \\
1992\end{array}$ & $\begin{array}{l}\text { pork LD } \\
\text { different genotypes }\end{array}$ & $\begin{array}{l}\text { dr: } 1: 10 \\
\text { range: } \mathrm{pH} \text { 6-7 }\end{array}$ & BC 60-64 \\
\hline Castellini and Somero 1981 & $\begin{array}{l}\text { pork adductor } \\
\text { beef temporalis }\end{array}$ & $\begin{array}{l}\text { dr: } 1: 2 \\
\text { range: } \mathrm{pH} 6-7 \\
\text { temp: } 37^{\circ} \mathrm{C}\end{array}$ & $\begin{array}{l}\text { pork BC } 50 \\
\text { beef BC } 52\end{array}$ \\
\hline $\begin{array}{l}\text { Rao and Gault } \\
1989\end{array}$ & beef LD & $\begin{array}{l}\text { dr: } 1: 9 \\
\text { range: ult.pH - } 3\end{array}$ & $\begin{array}{l}\mathrm{pHmin} 5.0 \\
\mathrm{BCmin} 49\end{array}$ \\
\hline $\begin{array}{l}\text { Bendall and } \\
\text { Wismer-Pedersen } 1962\end{array}$ & pork myofibrils & $\begin{array}{l}\mathrm{dr}: 1: 4 \\
\leftrightarrow \\
\text { range: } \mathrm{pH} 1.8-11\end{array}$ & $\begin{array}{l}\text { no minimum } \\
\text { no maximum }\end{array}$ \\
\hline $\begin{array}{l}\text { Connell and Howgate } \\
1964\end{array}$ & $\begin{array}{l}\text { beef and tuna } \\
\text { myofibrils }\end{array}$ & $\begin{array}{l}\text { dr: } 2-3 \% \text { solut. } \\
\leftrightarrow \\
\text { range: } \mathrm{pH} 2-12\end{array}$ & $\begin{array}{l}\text { no minimum } \\
\text { no maximum }\end{array}$ \\
\hline
\end{tabular}

a dr: dilution ratio

adj.: $\mathrm{pH}$ adjusted to the $\mathrm{pH}$ value indicated before titration

$\leftrightarrow$ : two separate titrations starting from intrinsic $\mathrm{pH}$ of the sample

range (in column 'method'): titrated $\mathrm{pH}$ range

${ }^{b}$ The unit for buffering capacity (BC) is $\mathrm{mmol} \mathrm{H}^{+} /\left(\mathrm{pH}^{*} \mathrm{~kg}\right.$ meat) and range indicates the $\mathrm{pH}$ range for which the $\mathrm{BC}$ value is valid.

For other abbr.: see later

${ }^{c} \mathrm{LD}=$ longissimus 
The present study focused on determining the buffering capacity of some dark and light beef, pork and poultry muscles and the effect of dilution on the buffering capacity curve.

\section{Materials and methods}

Buffering capacity was determined from the $m$. longissimus (LD) and $m$. triceps brachii (TB) muscles of ten porcine and ten bovine carcasses. The samples were excised from the carcass one day after slaughter, then homogenized with a Moulinette cutter (Moulinex, Italy) and stored frozen until measurement. Samples from different animals were assayed separately and single titrations were carried out.

Breast muscles from four broilers were homogenized to form one sample (B), as were the leg-thigh muscles (L). Titrations were carried out in triplicate.

Each sample was homogenized in a Moulinette cutter (Moulinex, Italy), then two $10 \mathrm{~g}$ aliquots were weighed out and separately homogenized with distilled water using a Ultra-Turrax T25 (Janke \& Kunkel, Germany). Sample/water ratios used were $10 \mathrm{~g}$ sample/100 ml water (1:10), $10 \mathrm{~g}$ sample/10 $\mathrm{ml}$ water $(1: 1)$ and $10 \mathrm{~g}$ sample/0 $\mathrm{ml}$ water (1:0). The homogenates were titrated using $0.1 \mathrm{~N} \mathrm{HCl}$ and $0.1 \mathrm{~N} \mathrm{NaOH}$. Additions of $1 \mathrm{ml}$ at two minutes intervals were used. The homogenates were stirred during titration. Titrations were carried out at room temperature. Electrodes used were Ross Sure-Flow 8172BN (Orion Research AG, Switzerland) and Ingold LoT406-M6-DXK 'Xerolyt' (Ingold Messtechnik GmbH, Germany)

The titration curve for the $\mathrm{pH}$ range 4-9 was obtained by combining data from the two titrations. Buffering capacity was calculated for each increment of acid and base as described by Hill et al. (1985).

$\mathrm{Bc}_{\mathrm{n}}=\Delta \mathrm{A} / \Delta \mathrm{pH}$,

where

$\Delta \mathrm{A}=$ the increment of acid or base, 
$\Delta \mathrm{pH}=$ the corresponding change in $\mathrm{pH}$, and

$\mathrm{BC}_{\mathrm{n}}=$ the average buffering capacity for the range between two successive observations.

$\mathrm{BC}_{\mathrm{n}}$ values were plotted against the midpoint of each respective pair of $\mathrm{pH}$ values. Curves were fitted using the spline smoothing procedure (SAS/GRAPH 'GPLOT' subroutine). The $\mathrm{pH}$ and $\mathrm{BC}$ values for the minimum and maximum points were read from the $\mathrm{BC}$ curve. The consumption of the titrant was read from the titration curve. The accuracy for reading the coordinates of the minimum and maximum points was for the buffering capacity curve: $\mathrm{BC}$ values $\pm 0.1\left[\mathrm{mmol} \mathrm{H}^{+} /\left(\mathrm{pH}^{*} \mathrm{~kg}\right.\right.$ meat $\left.)\right]$ and $\mathrm{pH}$ values \pm 0.01 , and for the titration curve: consumption values $\pm 1\left[\mathrm{mmol} \mathrm{H}^{+} /\left(\mathrm{pH}^{*} \mathrm{~kg}\right.\right.$ meat $\left.)\right]$.

Averages of $\mathrm{pH}$ values, not hydrogen ion concentrations, were used in calculations. The difference between successive $\mathrm{pH}$ measurements was usually about 0.1-0.2 units. With this level of difference no substantial error arises, even if the average is calculated using $\mathrm{pH}$ values and not hydronium ion concentrations (Hofmann, 1973).

In the tables, the following buffering capacity curve parameters appear:

initpH the $\mathrm{pH}$ of diluted sample and initial $\mathrm{pH}$ for titration

$\mathrm{pHmin} \quad$ the $\mathrm{pH}$ value of the minimum point of the buffering capacity curve at $\mathrm{pH}$ range 5-6

BCmin the $\mathrm{BC}$ value of the minimum point of the buffering capacity curve [mmol $\mathrm{H}^{+} /\left(\mathrm{pH}^{*} \mathrm{~kg}\right.$ meat $\left.)\right]$ at $\mathrm{pH}$ range 5-6

$\mathrm{pHmax}$ the $\mathrm{pH}$ value of the maximum point of the buffering capacity curve at $\mathrm{pH}$ range 6.5-7

BCmax the $\mathrm{BC}$ value of the maximum point of the buffering capacity curve [mmol $\mathrm{H}^{+} /\left(\mathrm{pH}^{*} \mathrm{~kg}\right.$ meat $\left.)\right]$ at $\mathrm{pH}$ range 6.5-7

cons consumption of titrant measured from the titration curve in $\mathrm{pH}$ range 5.5-7.0, $\left[\mathrm{mmol} \mathrm{H}^{+} / \mathrm{kg}\right.$ meat]. 


\section{Results and discussion}

\subsection{Pork, beef and broiler}

Tables 2-4 show the parameters of the BC curves for beef, pork and broiler samples. The difference in BC between LD and TB muscles in both pork and beef (Tables 2 and 3) were small, but in accordance with the expectation based on fiber type composition. Differences between corresponding muscles in beef and pork, respectively, were also small.

The differing amounts of carnosine and anserine explain the observed differences in $\mathrm{BC}$. Carnagie et al. (1982) give a dipeptide concentration of $25 \mathrm{mmol} / \mathrm{kg}$ for LD muscle of pig. The corresponding value for TB muscle is not given, but they give a value of $14 \mathrm{mmol} / \mathrm{kg}$ for $m$. trapezius, a muscle resembling $m$. triceps brachii in fiber type composition (Ruusunen, 1994) and anatomical location. Based on these values, a difference of about $6.5 \mathrm{mmol} \mathrm{H}^{+} /\left(\mathrm{pH}^{*} \mathrm{~kg}\right)$ in the $\mathrm{BCmax}$ values of these muscles could be expected, which is $81 \%$ of the observed difference $8 \mathrm{mmol} \mathrm{H}^{+} /\left(\mathrm{pH}^{*} \mathrm{~kg}\right)$.

The difference in the buffering capacity maximum value (BCmax) between beef muscles was very small. The BCmax of LD muscle was $3 \mathrm{mmol} \mathrm{H}^{+} /\left(\mathrm{pH}^{*} \mathrm{~kg}\right)$ higher than that of the TB muscle. Also in other studies (Bendall et al., 1976; Bendall, 1979; Talmant et al., 1986; Rao and Gault, 1989), the observed differences in the buffering capacity of beef LD and TB muscles are small. Differences between beef muscles in the content of chemical compounds affecting buffering capacity are so small that no great difference in buffering capacity is to be expected on that basis. Rao and Gault (1989) give a dipeptide concentration of $25 \mathrm{mmol} / \mathrm{kg}$ for LD muscle and $20 \mathrm{mmol} / \mathrm{kg}$ for TB muscle of beef. Based on these values, a difference of about 2.9 mmol H $\mathrm{H}^{+} /\left(\mathrm{pH}^{*} \mathrm{~kg}\right)$ in the BCmax values of these muscles could be expected. 
Table 2. The means and standard deviations of the parameters of the buffering capacity curves of pork samples. ( $\mathrm{N}=10$, different animals)

\begin{tabular}{lll}
\hline \hline & pork LD 1:10 & pork TB 1:10 \\
\hline pHinit & $5.44^{\mathrm{b}} \pm 0.06$ & $5.90^{\mathrm{a}} \pm 0.14$ \\
pHmin & $5.56^{\mathrm{b}} \pm 0.04$ & $5.64^{\mathrm{a}} \pm 0.04$ \\
BCmin & $38.9^{\mathrm{a}} \pm 2.2$ & $32.2^{\mathrm{b}} \pm 1.9$ \\
pHmax & $6.65^{\mathrm{b}} \pm 0.06$ & $6.69^{\mathrm{a}} \pm 0.0$ \\
BCmax & $65.4^{\mathrm{a}} \pm 3.6$ & $57.4^{\mathrm{b}} \pm 4.0$ \\
cons & $84^{\mathrm{a}} \pm 5$ & $70^{\mathrm{b}} \pm 4$ \\
\hline \hline & & \\
\hline \hline & pork LD 1:1 & pork TB 1:1 \\
\hline pHinit & $5.49^{\mathrm{b}} \pm 0.02$ & $5.85^{\mathrm{a}} \pm 0.11$ \\
pHmin & $5.70^{\mathrm{b}} \pm 0.05$ & $5.85^{\mathrm{a}} \pm 0.05$ \\
BCmin & $48.9^{\mathrm{a}} \pm 1.8$ & $40.3^{\mathrm{b}} \pm 1.2$ \\
pHmax & $6.69^{\mathrm{b}} \pm 0.05$ & $6.78^{\mathrm{a}} \pm 0.04$ \\
BCmax & $57.2^{\mathrm{a}} \pm 2.1$ & $48.8^{\mathrm{b}} \pm 2.0$ \\
cons & $82^{\mathrm{a}} \pm 3$ & $69^{\mathrm{b}} \pm 3$ \\
\hline
\end{tabular}

$\overline{\mathrm{a}, \mathrm{b}}$ Means within a row with different superscripts are significantly different $(\mathrm{p}<0.05)$.

Table 3. The means and standard deviations of the parameters of the buffering capacity curves of beef samples. ( $\mathrm{N}=10$, different animals)

\begin{tabular}{lll}
\hline \hline & beef LD 1:10 & beef TB 1:10 \\
\hline pHinit & $5.77 \pm 0.30$ & $5.84 \pm 0.32$ \\
pHmin & $5.56 \pm 0.06$ & $5.60 \pm 0.04$ \\
BCmin & $40.5 \pm 3.2$ & $37.6 \pm 3.6$ \\
pHmax & $6.68 \pm 0.1$ & $6.70 \pm 0.09$ \\
BCmax & $61.3 \pm 3.8$ & $58.2 \pm 4.8$ \\
cons & $80 \pm 2$ & $75 \pm 6$ \\
\hline
\end{tabular}

\begin{tabular}{lll}
\hline \hline & beef LD 1:1 & beef TB 1:1 \\
\hline pHinit & $5.71 \pm 0.29$ & $5.78 \pm 0.30$ \\
pHmin & $5.83 \pm 0.13$ & $5.82 \pm 0.14$
\end{tabular}




$\begin{array}{lll}\text { BCmin } & 50.9^{\mathrm{a}} \pm 2.9 & 47.2^{\mathrm{b}} \pm 4.0 \\ \text { pHmax } & 6.66 \pm 0.12 & 6.69 \pm 0.11 \\ \text { BCmax } & 57.3 \pm 3.8 & 53.7 \pm 4.4 \\ \text { cons } & 82 \pm 5 & 77 \pm 6\end{array}$

$\overline{\mathrm{a}, \mathrm{b}}$ Means within a row with different superscripts are significantly different $(\mathrm{p}<0.05)$.

Table 4. The means and standard deviations of parameters of the buffering capacity curves of broiler breast (B) and leg-thigh (L) muscles. $(\mathrm{N}=3)$

\begin{tabular}{lll}
\hline \hline & B 1:10 & L $1: 10$ \\
\hline pHinit & $5.84^{\mathrm{b}} \pm 0.06$ & $6.58^{\mathrm{a}} \pm 0.07$ \\
pHmin & $5.60 \pm 0.06$ & $5.61 \pm 0.01$ \\
BCmin & $38.3^{\mathrm{a}} \pm 0.7$ & $30.4^{\mathrm{b}} \pm 0.5$ \\
pHmax & $6.95 \pm 0.06$ & $6.92 \pm 0.04$ \\
BCmax & $77.8^{\mathrm{a}} \pm 6.1$ & $50.8^{\mathrm{b}} \pm 4.3$ \\
cons & $88^{\mathrm{a}} \pm 5$ & $63^{\mathrm{b}} \pm 4$ \\
\hline \hline & & \\
\hline \hline & $\mathrm{B} 1: 1$ & $\mathrm{~L} 1: 1$ \\
pHinit & $5.77^{\mathrm{b}} \pm 0.03$ & $6.54^{\mathrm{a}} \pm 0.04$ \\
pHmin & $5.79 \pm 0.03$ & $6.00 \pm 0.30$ \\
BCmin & $48.9^{\mathrm{a}} \pm 2.2$ & $39.5^{\mathrm{b}} \pm 2.6$ \\
pHmax & $6.92 \pm 0.05$ & $6.88 \pm 0.22$ \\
BCmax & $71.1^{\mathrm{a}} \pm 2.8$ & $44.7^{\mathrm{b}} \pm 3.3$ \\
cons & $88^{\mathrm{a}} \pm 3$ & $64^{\mathrm{b}} \pm 4$ \\
\hline
\end{tabular}

$\overline{\mathrm{a}, \mathrm{b}}$ Means within a row with different superscripts are significantly different $(\mathrm{p}<0.05)$. 
Broiler breast and leg muscles differ greatly in their physiological characteristics. Broiler breast muscle contains almost exclusively white fibers. Papinaho et al. (1996) gives the following distributions for broilermuscles: $m$. pectoralis red fibers $0 \%$, intermediate $0 \%$ and white fibers $100 \%$ and $m$. biceps femoris red fibers $12 \%$, intermediate $0.5 \%$ and white fibers $87.5 \%$. For the $m$. sartorius muscle in broiler leg the fiber type distribution is red fibers $25-30 \%$, intermediate 40-50\% and white 20-30\% (Aberle and Stewart, 1983; Aberle et al., 1978).

The lactic acid content of postrigor broiler breast muscle is about $100 \mathrm{mmol} / \mathrm{kg}$ and that of leg muscle about $50 \mathrm{mmol} / \mathrm{kg}$. But the effect of lactic acid on buffering capacity in the $\mathrm{pH}$ range studied is small, because the $\mathrm{pK}$ value of lactic acid does not coincide with $\mathrm{pH}$ range studied. The difference in lactic acid concentration only accounts for a difference of less than $1 \mathrm{mmol}$ $\mathrm{H}^{+} /\left(\mathrm{pH}^{*} \mathrm{~kg}\right)$ in buffering capacity at $\mathrm{pH}$ 6.9.

The large difference in muscle physiology is also apparent in the large difference in dipeptide contents (Plowman and Close, 1988). We observed a difference of approximately $27 \mathrm{mmol}$ $\mathrm{H}^{+} /\left(\mathrm{pH}^{*} \mathrm{~kg}\right)$ in $\mathrm{BCmax}$ values between leg-thigh and breast muscles with both dilution ratios. On the basis of the dipeptide contents as indicated by Plowman and Close (1988), a difference of approximately $21 \mathrm{mmol} \mathrm{H} /\left(\mathrm{pH}^{*} \mathrm{~kg}\right)$ could be expected. As a result, the difference in dipeptide content of the muscles accounts for about $80 \%$ of the difference in BCmax value.

\subsection{The effect of dilution on buffering capacity curve}

Table 5 shows the parameters of buffering capacity curves obtained using different dilutions. Sample/water ratios used were $10 \mathrm{~g}$ sample/100 $\mathrm{ml}$ water (1:10) and $10 \mathrm{~g}$ sample/10 $\mathrm{ml}$ water (1:1). In addition, titrations with no preceding dilution were carried out. 
Table 5. The parameters of the buffering capacity curve for a beef sample at different dilution ratios. Values are means \pm S.D.(1:0 titration was begun without added water. Titrations were carried out with $0.1 \mathrm{~N}$ solutions, such that when the titration was concluded $(\mathrm{pH}$ values 4.4 and 7.8 ), the dilution was approximately $1: 1$ ).

\begin{tabular}{llll}
\hline \hline & $1: 10(\mathrm{~N}=4)$ & $1: 1(\mathrm{~N}=4)$ & $1: 0(\mathrm{~N}=5)$ \\
\hline pHinit & $5.67^{\mathrm{b}} \pm 0.04$ & $5.60^{\mathrm{c}} \pm 0.00$ & $5.73^{\mathrm{a}} \pm 0.02$ \\
pHmin & $5.59^{\mathrm{b}} \pm 0.06$ & $5.74^{\mathrm{ab}} \pm 0.08$ & $5.82^{\mathrm{a}} \pm 0.05$ \\
BCmin & $33.2^{\mathrm{b}} \pm 1.8$ & $43.2^{\mathrm{a}} \pm 2.3$ & $46.5^{\mathrm{a}} \pm 2.4$ \\
pHmax & $6.98^{\mathrm{a}} \pm 0.09$ & $6.87^{\mathrm{ab}} \pm 0.08$ & $6.72^{\mathrm{b}} \pm 0.04$ \\
BCmax & $64.6 \pm 10.5$ & $60.2 \pm 5.1$ & $55.2 \pm 1.5$ \\
cons & $74 \pm 5$ & $78 \pm 6$ & $76 \pm 1$ \\
\hline
\end{tabular}

$\overline{\mathrm{a}, \mathrm{b}, \mathrm{c}}$ Means within a row with different superscripts are significantly different $(\mathrm{p}<0.05)$.

As a summary of Table 5 the following trends can be seen:

- initial $\mathrm{pH}$

- pHmin

- BCmin

- pHmax

- BCmax

- consumption no systematic differences between dilution ratios

lower with greater dilution

smaller with greater dilution

higher with greater dilution

greater with greater dilution

no systematic differences.

Titrations with different dilutions revealed the following trends. When less diluted, the 'hump' in the titration curve grew smaller and the titration curve became straighter. Changes in the titration curve were small and difficult to observe, but in the buffering capacity curve, which is the reciprocal of the derivative of the titration curve, changes were clearly visible. Fig 1 shows a typical example, a set of three individual buffering capacity curves of a same sample obtained with different dilutions.

The buffering capacity value at the maximum point on the curve was greater when more water was used, and the buffering capacity value at the minimum point was correspondingly smaller. The buffering capacity (BCmax) at the maximum point on the buffering capacity curves was approximately 5-8 $\mathrm{mmol} \mathrm{H}^{+} /\left(\mathrm{pH}^{*} \mathrm{~kg}\right)$ greater using a dilution ratio of $1: 10$ than with a dilution ratio of $1: 1$. The buffering capacity $(\mathrm{BCmin})$ at the minimum point on the buffering capacity curve was approximately $10 \mathrm{mmol} \mathrm{H}^{+} /\left(\mathrm{pH}^{*} \mathrm{~kg}\right)$ smaller using a dilution ratio of 1:10 than with a dilution ratio of $1: 1$. 
The $\mathrm{pH}$ values of the minimum and maximum points on the buffering capacity curve also changed as the amount of dilution changed. The $\mathrm{pH}$ value at the minimum point on the buffering capacity curve ( $\mathrm{pHmin}$ ) obtained by the dilution ratio 1:10 was approximately 0.15 $\mathrm{pH}$ units lower than with the dilution ratio 1:1. The $\mathrm{pH}$ value at the maximum point on the buffering capacity curve ( $\mathrm{pHmax}$ ) obtained by the dilution ratio 1:10 was approximately $0.1 \mathrm{pH}$ units higher than with the dilution ratio $1: 1$.

$\mathrm{pK}_{\mathrm{a}}$ values are dependent on ionic strength. The $\mathrm{pK}_{\mathrm{a}}$ value of phosphoric acid decreases and the $\mathrm{pK}_{\mathrm{a}}$ value of imidazole increases when ionic strength increases (Freifelder, 1985). This dependance of activity coefficients and ionic strength is valid only in dilute solutions and should not be applied as such to a concentrated solution or to solutions containing macromolecules.

However, the results obtained in this study seem to indicate a similar change in $\mathrm{pK}_{\mathrm{a}}$ values. When the sample was less diluted, the maximum in the buffering capacity curve broadened, $\mathrm{BCmax}$ droped, and buffering capacity in the range pHmin-pHmax increased. These changes can be explained by assuming that the difference in $\mathrm{pK}_{\mathrm{a}}$ values of the compounds forming the buffering capacity maximum in the $\mathrm{pH}$ range 6.5-7 increased.

As a buffering capacity curve has a specific shape based on its mathematical equation, spline smoothing is not the best way to analyse this data, because it does not fit a curve of this specific shape and thus fails to reveal the overlapping of peaks. More information could be gained from the titration data if it were analysed by a peak-fitting program (de Levie et al., 1998). 


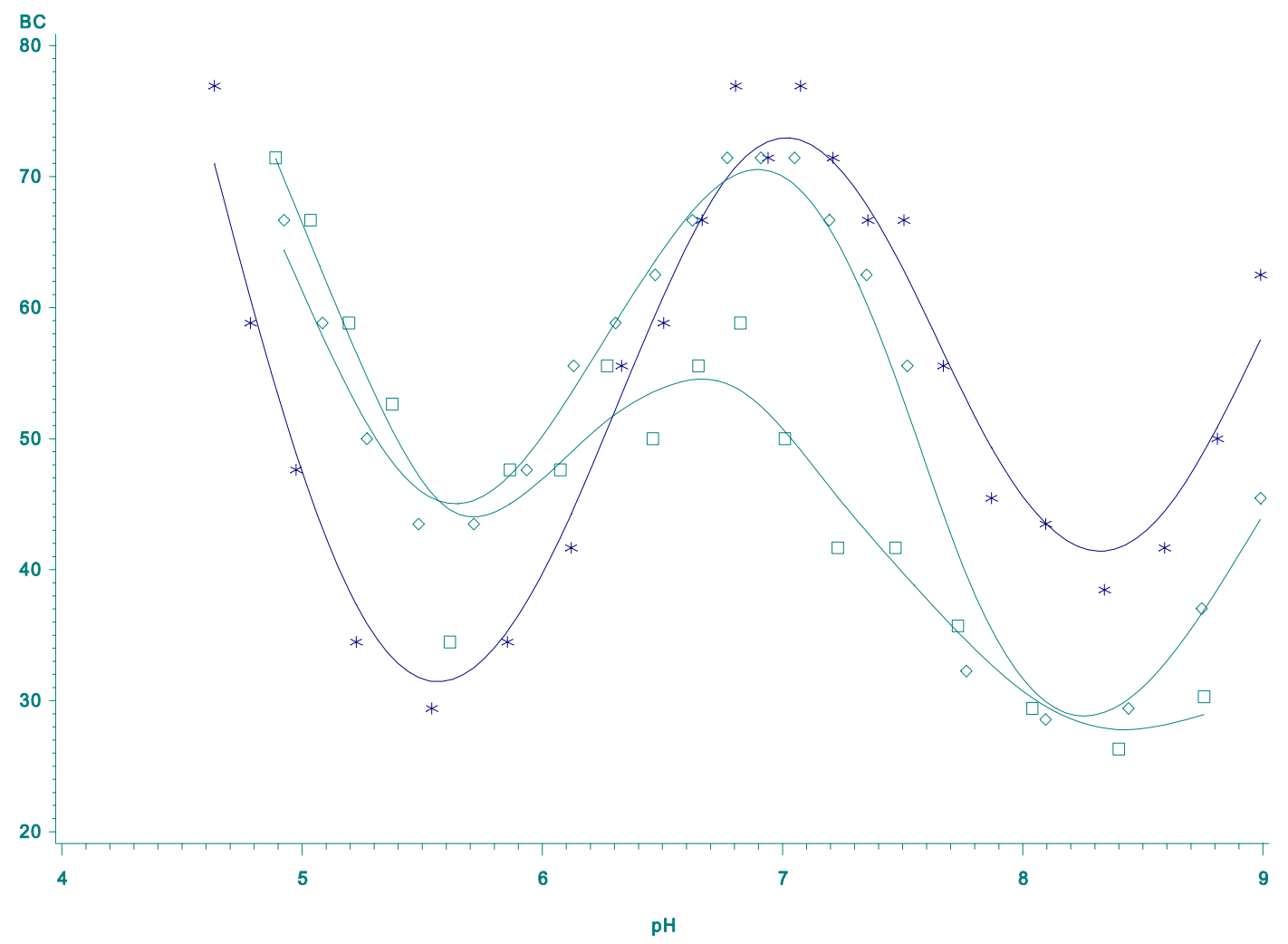

Fig 1. Buffering capacity curves obtained with different dilutions.

Sample-water ratios 1:10 (*);

$1: 1(\diamond)$

$1: 0(\square) ;$

sample: beef,

horizontal axis: $\mathrm{pH}$

vertical axis: buffering capacity, $\mathrm{mmol} \mathrm{H}^{+} /\left(\mathrm{pH}^{*} \mathrm{~kg}\right)$. 


\subsection{The average buffering capacity values}

Dilution makes it easier to carry out titrations of meat samples, but when using results obtained in this way, one needs to be sure that they are applicable to the situation in question. The buffering capacity of meat as it is, with no dilution, is often of interest. For example, the fall in $\mathrm{pH}$ during post mortem reaction sequence is a function of both the amount of lactic acid produced and of buffering capacity. The ultimate $\mathrm{pH}$ of a muscle is a function of these two independent factors.

It seems possible to estimate the buffering capacity of the original meat sample from the buffering capacity curves of diluted samples. When a dilution ratio of 1:10 was used for determining the buffering capacity curve, the curve obtained was pronounced curving. But when the sample was not diluted the buffering capacity remained quite constant in the $\mathrm{pH}$ range 5.5-7.0. When a single value is needed, as an estimate of buffering capacity, a suitable estimate in the $\mathrm{pH}$ range 5.5-7.0 is the mean of the $\mathrm{BCmax}$ and $\mathrm{BCmin}$ values determined using dilution ratio 1:10. Calculated in this way the buffering capacities of the different sample types studied (beef LD, beef TB, pork LD, pork TB, broiler breast, broiler leg-thigh) do not differ very dramatically from each other (Table 6). These values are valid in the $\mathrm{pH}$ range 5.5-7.0. In the $\mathrm{pH}$ range $<5.5$ the buffering capacity strongly increases, e.g. if buffering capacity at $\mathrm{pH} 5.5$ is $50 \mathrm{mmol} \mathrm{H}^{+} /\left(\mathrm{pH}^{*} \mathrm{~kg}\right)$, at $\mathrm{pH} 5.0$ it is approximately $70 \mathrm{mmol} \mathrm{H}^{+} /\left(\mathrm{pH}^{*} \mathrm{~kg}\right)$ and at $\mathrm{pH} 4.580-90$ $\mathrm{mmol} \mathrm{H} /\left(\mathrm{pH}^{*} \mathrm{~kg}\right)$.

Table 6. Mean buffering capacities in $\mathrm{pH}$ range 5.5-7.0.

\begin{tabular}{lc}
\hline \hline & $\mathrm{BC}$ \\
\hline beef LD & 51 \\
beef TB & 48 \\
pork LD & 52 \\
pork TB & 45 \\
broiler breast & 58 \\
broiler leg-thigh & 41 \\
\hline
\end{tabular}




\section{Conclusions}

1. The method of titration, mainly the amount of dilution used, greatly affects the shape of the obtained buffering capacity curve. When a more dilute suspension is used, the curve has more distinct maximum and minimum points, and the difference of $\mathrm{BCmax}$ and $\mathrm{BCmin}$ is greater than when a more concentrated suspension is used. All in all, it appears that the less added water is used when titrating, the more linear the titration curve becomes. As a consequence, the buffering capacity curve approaches a shape with no distinct maximum or minimum points. When no added water is used, the buffering capacity seems to be quite constant in the $\mathrm{pH}$ range 5.8-6.5.

2. Calculated as a mean of BCmax and $\mathrm{BCmin}$, the buffering capacity values in $\mathrm{pH}$ range 5.5-7.0 were for beef $m$. longissimus muscle $51 \mathrm{mmol} \mathrm{H}^{+} /\left(\mathrm{pH}^{*} \mathrm{~kg}\right)$, for pork $m$. longissimus $52 \mathrm{mmol} \mathrm{H}^{+} /(\mathrm{pH} * \mathrm{~kg})$, for beef $m$. triceps brachii $48 \mathrm{mmol} \mathrm{H}^{+} /\left(\mathrm{pH}^{*} \mathrm{~kg}\right)$ and

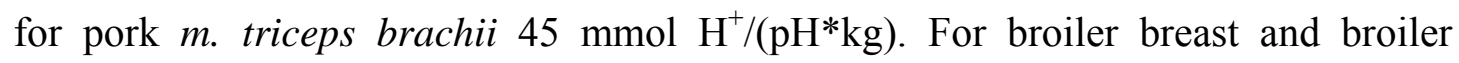
leg-thigh muscles the corresponding values were 58 and $41 \mathrm{mmol} \mathrm{H}^{+} /\left(\mathrm{pH}^{*} \mathrm{~kg}\right)$. Differences in buffering capacity between the muscles can be explained by the variation in dipeptide content.

3. Consequently, it does not seem to be possible to relate the variation in technological properties of postrigor meat (e.g. Water binding capacity) to variation in buffering capacity. Differences in buffering capacities between different kinds of samples are too small to give a solid basis for expecting differences in their $\mathrm{pH}$ patterns.

\section{References}

Aberle, E.D., Addis, P.B., Shoffner, R.N., 1978. Fiber types in skeletal muscles of broiler- and layer-type chickens. Poultry Science 58:1210-1212.

Aberle, E.D., Stewart, T.S., 1983. Growth of fiber types and apparent fiber number in skeletal muscles of broiler- and layer-type chickens. Growth 47:135-144.

Bate-Smith, E.C., 1938. The buffering of muscles in rigor; protein, phosphate and carnosine. Journal of Physiology 92:336-343.

Bendall, J.R., Wismer-Pedersen, J., 1962. Some properties of the fibrillar proteins of normal and watery pork muscle. Journal of Food Science 27:144-159.

Bendall, J.R., Ketteridge, C.C., George, A.R., 1976. The electrical stimulation of beef carcasses. Journal of the Science of Food and Agriculture 27:1123-1131.

Bendall, J.R., 1979. Relations between muscle $\mathrm{pH}$ and important biochemical parameters during the post-mortem changes in mammalian muscles. Meat Science 3:143-157. 
Carnegie, P.R., Kui, P.H., Bell, A.W., 1982. Ophidine (ß-alanyl-L-3-methylhistidine, 'balenine') and other histidine dipeptides in pig muscles and tinned hams. Journal of the Science of Food and Agriculture 33:795-801.

Castellini, M.A., Somero, G.N., 1981. Buffering capacity of vertebrate muscle: Correlations with potentials for anaerobic function. Journal of Comparative Physiology 143:191-198.

Connell, J.J., Howgate, P.F., 1964. The hydrogen ion titration curves of native, heat-coagulated and frozen-stored myofibrills of cod and beef. Journal of Food Science 29:717-722.

de Levie, R., Moisio, T., Heikonen, M., 1998. Computer fitting of entire data sets, as exemplified by acid-base titrations. Kemia-Kemi 25:121-123.

Freifelder, D., 1985. Principles of Physical Chemistry. With Applications to the Biological Sciences. Jones and Bartlett Publishers, Inc. Boston. $808 \mathrm{p}$

Hamm, R., 1959. Das Pufferungsvermögen des Rindermuskels. Zeitschrift für Lebensmittel-Untersuchung und Forschung 109:337-347.

Hamm, R., Deatherage, F.E., 1960. Changes in hydration, solubility and charges of muscle proteins during heating of meat. Food Research 25:587-610.

Henckel, P., Jörgensen, P.F., Jensen, P., 1992. Glycogen content, buffering capacity and resting pH in live muscles of pigs of different halotane genotypes (a pilot project). Meat Science 32:131-138.

Hill, A.R., Irvine, D.M., Bullock, D.H., 1985. Buffer capacity of cheese wheys. Journal of Food Science 50:733-738.

Hofmann, K., 1973. Ist die Mittelwertbildung von pH-Werten zulässig? Fleischwirtschaft 1973:(2)258-259.

Honikel, K.O., Hamm, R., 1974. Über das Pufferungsvermögen des Fleisches und seine Veränderungen post mortem. Zeitschrift für Lebensmittel-Untersuchung und Forschung 156:145-152.

Monin, G., Sellier, P., 1985. Pork of low technological quality with a normal rate of muscle $\mathrm{pH}$ fall in the immediate post-mortem period: The case of the Hampshire breed. Meat Science 13:49-63.

Olsman, W.J., Slump, P. 1981. Methods of determination of connective tissue free muscle protein in meat products. In: Developments of Meat Science 2. p.195-240. Elsevier London.

Papinaho, P., Ruusunen, M., Suuronen, T., Fletcher, D., 1996. Relationship between muscle biochemical and meat quality properties of early deboned broiler breast. Journal of Applied Poultry Research 5:126-133.

Plowman, J.E., Close, E.A., 1988. An evaluation of a method to differentiate the species of origin of meats on the basis of the contents of anserine, balenine and carnosine in skeletal muscle. Journal of the Science of Food and Agriculture 45:69-78.

Rao, M.V., Gault, N.F.S., 1989. The influence of fibre-type composition and associated biochemical characteristics on the acid buffering capacities of several beef muscles. Meat Science 26:5-18.

Ruusunen, M., 1994. Muscle histochemical properties of different pig breeds in relation to meat quality. Diss., Dept. of Food Technology, University of Helsinki.

Sayre, R.N., Briskey, E.J., Hoekstra, W.G., 1963. Comparison of muscle characteristics and post-mortem glycolysis in three breeds of swine. Journal of Animal Science 22:1012-1020.

Sewell, D.A., Harris, R.C., Marlin, D.J., Dunnett, M., 1992. Estimation of the carnosine content of different fibre types in the middle gluteal muscle of the thoroughbred horse. Journal of Physiology 455:447-453.

Talmant, A., Monin, G., Briand, M., Dadet, M., Briand, Y., 1986. Activities of metabolic and contractile enzymes in 18 bovine muscles. Meat Science 18:23-40. 